\title{
KIRKWOOD ELECTED ROAD SUPERVISOR
}

\section{By JACOB E. REIZENSTEIN}

Lives there a pioneer in Iowa City, a resident of the oldtime "Iowa City township," who participated in an odd political joke, with a certain famous Iowan-a governor, state senator, United States senator, and member of a presidential cabinet, as a victim? The man in question was Hon. Samuel Jordan Kirkwood, and any old settler who voted at the election in question now must be at least 97 years of age.

That is not an impossibility, but he can answer "aye" to the opening query must be unusually, if not phenomenally linked with the history of the county. Yes, this happened 76 long years ago.

Mr. Kirkwood had returned to Iowa City in 1868 , to settle down on his old homestead on the highway that bears his name today. He had filled his seat in the Iowa senate (in the 6th and 7th general assemblies) his gubernational duties were performed; he had served in the United States senate; declined a ministerial post in Denmark tendered by President Abraham Lincoln.

He did not know it, in 1868, but his high political service was far from ended. Indeed, the people of Iowa named him governor again, in 1875, and President James A. Garfield called him to the post of Secretary of the Interior-which honor he accepted, resigning as. United States senator to take the position.

In 1868 , however, he was awarded a political post that provided the "joke" in question. Probably, never before, and likewise since, has any governor-senator-secretary been similarly "called from the plow" Cincinnatus-like, under such quaint circumstances.

He was elected road supervisor of Iowa City township. Did the former governor of Iowa decline the post? He did not. With smiling good humor, but with a determination and pledge to fulfill all duties with his wonted earn- 
estness and eagerness to serve well and faithfully the people of his community, he took the office that year.

That he carried out his pledge is demonstrated by a report filed by him with the township clerk, Attorney ("Major") Ira J. Alder, more than a year later, on Friday, November 12,1869 . In the dusty depths of the court house vaults, a generation later, a sworn statement was exhumed, bearing the governor's signature, and the attestation of Mr. Alder.

To the report was attached this affidavit: "S. J. Kirkwood, being duly sworn, says that the foregoing statement, of his accounts as supervisor of Road District No. 9 of Iowa City township, in said county, is just and true, as he verily believes." The document proves indubitably that, while America has become known, the world over, as the one land, where road supervisors may become governors and United States senators-and even presidents of the nation, it is also a country, where men in very high offices may serve in the lowliest, without losing dignity or fame. And the service in question began as a "joke"one that "back-fired!"-Iowa City Press-Citizen.

Jonas M. Poweshiek has been with the State Historical department twenty years. On his birthday, January 1, 1944, marking fifty years of his life and twenty years of service for the state, the staff of the department presented him with a pair of driving gloves and his wife and daughter with a box of candy. Jonas lives at Altoona, near the state capital, where he cultivates his ranch. On invitation he prepared the article about the Musquakie Indians engaged in World War II. His distinguished ancestor, Chief Poweshiek, whose camp was at one time near the Raccoon forks, might look down from the "happy hunting grounds" upon a scene quite different from that of a century ago along the Iowa and Des Moines valleys. 
Copyright of Annals of Iowa is the property of State of Iowa, by \& through the State Historical Society of Iowa and its content may not be copied or emailed to multiple sites or posted to a listserv without the copyright holder's express written permission. However, users may print, download, or email articles for individual use. 